\title{
PEMANFAATAN LINGKUNGAN SEKITAR DENGAN TEKNIK MIND MAPPING UNTUK MENINGKATKAN AKTIVITAS DAN HASIL BELAJAR SISWA PADA PELAJARAN IPS
}

\author{
Nur Khasanah ${ }^{1}$, Wahyu Sukartiningsih ${ }^{2}$, Waspodo Tjipto Subroto ${ }^{3}$ \\ ${ }^{1}$ Mahasiswa Program Pascasarjana, Prodi Pendidikan Dasar, Universitas Negeri Surabaya, \\ ${ }^{2 \& 3}$ Dosen Pascasarjana, Prodi Pendidikan Dasar, Universitas Negeri Surabaya \\ e-mail: ${ }^{1}$ mombeauty69@yahoo.co.id
}

\section{Received : $\quad$ Maret 2018}

Reviewed : April 2018

Accepted : Mei 2018

Published : $\quad$ Mei 2018
ABSTRACT

This research is a Classroom Action Research which aims to improve the activity and student learning outcomes using around environment with mind mapping techniq in the IV grade of SDI Al-Irsyad Tarakan. This study was conducted on January 5, 2017 to february 16, 2017.The research was carried out in three cycles of learning. Each cycle consists of two meetings. The research subject is the IV grade of SDI Al-Irsyad Tarakan which consists of 30 students in the second semester of the academic year 2016/2017. And the object of research is the students' learning activities and student learning outcomes. The result showed that the application of using around environment with mind mapping techniq in social studies material economic activity related to natural resources and other potentials in its region can increase the activity and student learning outcomes. It can be seen from the observation and analysis of data in each cycle. Increased students' activity can be seen from the increase of the percentage of students' activity in the first cycle is $75,19 \%$ become $82,13 \%$ in the second cycle and $87,72 \%$ in the third cycle. Improving student learning outcomes can be seen from the increase in the learning outcomes completeness in the first cycle is $63,33 \%$ become $76,67 \%$ in the second cycle and 93,33\% in the third cycle. Based on these results it can be concluded that the application of using aroud environment with mind mapping techniq in social studies material economic activity related to natural resources and other potential activity in its region can improve student learning activities and student learning outcomes the IV grade of SDI Al-Irsyad Tarakan.

Keywords: Contextual Teaching and Learning, Mind Mapping, Student Activity, Learning outcomes.

\section{ABSTRAK}

Penelitian ini merupakan penelitian tindakan kelas (PTK) yang bertujuan untuk meningkatkan aktivitas dan hasil belajar siswa dengan menerapkan pemanfaatan lingkungan sekitar dengan teknik Mind Mapping pada siswa kelas IV SDI Al-Irsyad Kota Tarakan. Penelitian ini dilakukan pada tanggal 5 Januari 2017 sampai dengan tanggal 16 Februari 2017. Penelitian ini dilaksanakan selama tiga siklus pembelajaran. Setiap siklus terdiri atas dua kali pertemuan. Subjek penelitian ini adalah siswa kelas IV SDI A-Irsyad Kota Tarakan yang berjumlah 30 siswa pada semester 2 tahun pelajaran 2016/2017, dan objek penelitiannya adalah aktivitas belajar siswa dan hasil belajar siswa. Hasil penelitian menunjukkan bahwa pemanfaatan lingkungan sekitar dengan teknik mind mapping pada pembelajaran IPS materi pokok aktivitas ekonomi yang berkaitan dengan sumber daya alam dan potensi lain di daerahnya, dapat meningkatkan aktivitas dan hasil belajar siswa. Hal ini dapat dilihat dari hasil pengamatan dan analisis data pada setiap siklus yang telah dilaksanakan. Peningkatan aktivitas siswa dapat dilihat dari peningkatan persentase aktivitas siswa pada siklus I sebesar $75,19 \%$ menjadi $82,13 \%$ pada siklus II dan $87,72 \%$ pada siklus III. Peningkatan hasil belajar siswa dapat dilihat dari peningkatan ketuntasan hasil belajar pada siklus I sebesar 63,33\%\% menjadi 76,67\% pada siklus II dan 93,33\% pada siklus III. Berdasarkan hasil penelitian ini dapat 
disimpulkan bahwa pemanfaatan lingkungan sekitar dengan teknik mind mapping dalam pembelajaran IPS materi pokok aktivitas ekonomi yang berkaitan dengan sumber daya alam dan potensi lain di daerahnya dapat meningkatkan aktivitas dan hasil belajar siswa kelas IV SDI Al-Irsyad Kota Tarakan

Kata Kunci: Contextual Teaching and Learning, Mind Mapping, Aktivitas Siswa, Hasil Belajar.

\section{PENDAHULUAN}

Pendidikan selalu berkembang dan dinamis mengikuti perkembangan zaman yang menuntut agar peserta didik mampu mempunyai pola pikir yang maju. Oleh karena itu perubahan atau perkembangan pendidikan adalah hal yang memang seharusnya terjadi sejalan dengan perubahan budaya kehidupan. Perubahan dalam arti perbaikan pendidikan pada semua tingkat perlu terus menerus dilakukan sebagai antisipasi kepentingan masa depan.

Di era saat ini, para siswa menghadapi berbagai risiko sejalan dengan perkembangan teknologi, ilmu pengetahuan, ekonomi dan sosial budaya yang begitu pesat, sehingga siswa dituntut untuk belajar lebih banyak dan proaktif agar mereka memiliki pengetahuan dan keterampilan/keahlian yang memadai. Para siswa saat ini hidup dalam dunia yang berbeda dan jauh lebih komplek dibanding zaman sebelumnya. Guru di sekolah sebagai sosok terdepan di dalam proses pendidikan, dituntut mampu memberikan pengetahuan, sikap, perilaku, dan keterampilan melalui strategi dan pola pembelajaran yang sesuai dengan tuntutan dan perkembangan zaman.

Mengacu pada Peraturan Pemerintah Nomor 19 Tahun 2005 tentang Standar Nasional Pendidikan, menyatakan pembelajaran dilaksanakan secara interaktif, inspiratif, menyenangkan, menantang, memotivasi peserta didik untuk berpartisipasi aktif, serta memberikan ruang yang cukup bagi prakarsa, kreativitas dan kemandirian sesuai dengan bakat, minat, dan perkembangan fisik serta psikologis peserta didik. Hal tersebut mengindikasikan bahwa hendaknya guru memfasilitasi peserta didik agar mereka mampu memahami materi pelajaran dengan menghubungkan pengetahuan yang dimilkinya dengan konteks kehidupan nyata sehari-hari melalui proses pembelajaran yang terencana dengan melibatkan peran aktif siswa.

Proses pembelajaran pendidikan IPS di jenjang persekolahan, baik pada tingkat pendidikan dasar maupun menengah, perlu adanya pembaharuan yang serius, karena pada kenyataannya selama ini masih banyak pendekatan pembelajaran yang masih bersifat konvensional, tidak terlihat adanya improvisasi dalam pembelajaran, jauh dari pendekatan pembelajaran yang modern sesuai dengan tuntutan zaman dan kondisi lingkungan sekitar siswa berada. Akibatnya siswa cenderung tidak tertarik dengan pelajaran yang diajarkan guru. Agar siswa memahami suatu konsep, biasanya guru lebih mengutamakan sistem hafalan semata dan kurang menekankan aspek penalaran. Padahal, untuk meningkatkan pemahaman siswa terhadap materi yang diajarkan diperlukan pendekatan dan teknik yang tepat dengan disertai penggunaan media pembelajaran yang menarik dan sesuai dengan materi, sehingga siswa dapat memahami materi tersebut

Menurut Susanto (2014:12), tujuan utama pembelajaran IPS ialah untuk mengembangkan potensi peserta didik agar peka terhadap masalah sosial yang terjadi di masyarakat, memiliki sikap mental positif terhadap perbaikan segala ketimpangan yang terjadi, dan terampil mengatasi setiap masalah yang terjadi sehari-hari baik yang menimpa dirinya sendiri maupun yang menimpa masyarakat. Hal ini berarti, tujuan pendidikan IPS bukan hanya sekedar membekali siswa dengan berbagai informasi yang berkaitan dengan hafalan (kognitif) saja, akan tetapi pendidikan IPS harus mampu mengembangkan keterampilan berpikir, agar siswa mampu mengkaji berbagai kenyataan sosial beserta permasalahannya. Tujuan yang harus dicapai oleh siswa sekolah dasar harus disesuaikan dengan taraf perkembangannya, yang dimulai dari pengenalan dan pemahaman lingkungan sekitar menuju lingkungan yang lebih luas.

Demikian pula dalam Kurikulum Tingkat Satuan Pendidikan (2006), pemerintah telah memberikan arah yang jelas pada tujuan dan ruang lingkup pembelajaran IPS, yaitu: (1) mengenal konsep-konsep yang berkaitan dengan kehidupan masyarakat dan lingkungannya; (2) memiliki kemampuan dasar untuk berpikir logis dan kritis, rasa ingin tahu, inkuiri, memecahkan masalah, dan keterampilan dalam kehidupan sosial; (3) memiliki komitmen dan kesadaran terhadap nilai-nilai sosial dan kemanusiaan; (4) memiliki kemampuan berkomunikasi, bekerjasama, dan berkompetisi dalam masyarakat yang majemuk di tingkat lokal, nasional, dan global.

Berdasarkan hasil observasi di SDI Al- Irsyad Kota Tarakan, terdapat permasalahan pembelajaran yang berasal dari faktor guru dan siswa. Guru lebih banyak 
menyampaikan materi dengan menggunakan metode ceramah, kemudian siswa membuat ringkasan dari buku dan diberi tugas menghafalkan materi-materi yang penting. Guru belum menggunakan pendekatan, metode dan media pembelajaran yang bervariasi dan masih kurangnya pengetahuan guru akan hal tersebut. Sedangkan dari faktor siswa, siswa cenderung kurang antusias, pasif, dan terkadang asyik berbicara dengan temannya karena siswa tidak tertarik dengan proses pembelajaran yang hanya berpusat pada guru.

Pembelajaran yang berpusat pada guru tersebut pada akhirnya menyebabkan rendahnya aktivitas belajar dan hasil belajar siswa. Hanya beberapa siswa yang aktif, sedangkan sebagian besar siswa cenderung pasif. Rendahnya hasil belajar siswa dapat dilihat dari hasil ulangan harian pelajaran IPS siswa kelas IV SDI Al-Irsyad Kota Tarakan menunjukkan nilai rata-rata kelas belum mencapai Kriteria Ketuntasan Minimal (KKM).

Salah satu materi yang terdapat dalam pembelajaran IPS di kelas IV SD yang menunjukkan rendahnya aktivitas dan hasil belajar siswa SDI Al-Irsyad Kota Tarakan adalah materi aktivitas ekonomi yang berkaitan dengan sumber daya alam dan potensi lain di daerahnya. Sebagaimana yang diketahui bahwa aktivitas ekonomi masyarakat di Kota Tarakan sebagian besar di bidang perikanan, diantaranya budi daya ikan, udang, serta kepiting. Selain itu aktivitas ekonomi yang paling khas di Kota Tarakan adalah budi daya kepiting Soka dan pembuatan ikan asin tipis yang berasal dari ikan Pepija. Dalam kegiatan pembelajarannya, materi tersebut hanya disampaikan secara abstrak dan teoritis bahkan secara luas. Siswa tidak berhubungan langsung dengan aktivitas ekonomi yang ada di lingkungan sekitarnya. Hal ini menyebabkan aktivitas dan hasil belajar siswa rendah.

Permasalahan tersebut didukung oleh data dokumen hasil belajar siswa kelas IV semester II tahun ajaran 2015/2016 pada mata pelajaran IPS materi aktivitas ekonomi yang berkaitan dengan sumber daya alam dan potensi lain di daerahnya menunjukkan rata-rata 59,48 dan ketuntasan klasikal hanya $25,81 \%$ dari 31 siswa hanya 8 siswa yang berhasil mencapai kriteria ketuntasan minimal yang ditetapkan sekolah yaitu 70. Data hasil belajar ditunjukkan dengan nilai terendah 32 dan nilai tertinggi 80 .

\section{TINJAUAN PUSTAKA}

Sehubungan dengan permasalahan yang dikemukakan di atas, maka perlu dicari solusinya. Setelah melakukan refleksi bersama guru kelas, supaya aktivitas dan hasil belajar siswa meningkat khususnya pada materi tersebut diperlukan penerapan pembelajaran yang memanfaatkan lingkungan sekitar yaitu siswa belajar melalui kegiatan mengalami sendiri dalam lingkungan yang alamiah. Proses Pembelajaran yang memanfaatkan lingkungan sekitar memiliki kemampuan untuk membangun makna belajar yang lebih kuat, kemudian diikuti dengan berfungsinya struktur kognitif siswa secara lebih optimal sehingga akan berkesan lama dalam ingatan (Kosasih, 2014:66)

Salah satu pendekatan yang tepat yang diharapkan dapat memberi kesempatan kepada siswa untuk mengeksplorasi lingkungan sekitarnya sehingga memperoleh hasil belajar yang lebih bermakna adalah pembelajaran menggunakan pendekatan Contextual Teaching and Learning (CTL).

Pendekatan CTL merupakan suatu konsep yang membantu guru mengaitkan konten mata pelajaran dengan situasi dunia nyata dan mendorong siswa membuat hubungan antara pengetahuan yang dimilikinya dengan penerapannya dalam kehidupan sehari-hari. Dalam penerapannya di kelas, pendekatan pembelajaran $C T L$ melibatkan tujuh komponen utama pembelajaran, yakni: kontruktivisme (contructivism), bertanya (questioning), menemukan (inquiry), masyarakat belajar (learning community), pemodelan (modeling), refleksi (reflection) dan penilaian sebenarnya (authentic assessment) (Riyanto,2014: 163).

Sears dan Hersh (dalam Glynn dan Winter, 2004) mengungkapkan bahwa $C T L$ menekankan penggunaan konsep dan keterampilan proses dalam konteks dunia nyata yang terkait dengan latar belakang siswa yang bermacammacam. Pendekatan ini memotivasi siswa untuk membuat hubungan antara pengetahuan dan penerapan dalam kehidupan mereka sebagai anggota keluarga, penduduk, dan pekerja dan menyertakan kerja keras pada kebutuhan pembelajaran.

Materi pelajaran akan lebih berarti bagi siswa jika disajikan dengan melibatkan para siswa dalam aktivitas penting yang membantu mereka mengaitkan materi dengan konteks kehidupan nyata yang mereka hadapi. Dengan mengaitkan keduanya, para siswa melihat makna di dalam tugas sekolah. Ketika para siswa menyusun proyek atau menemukan permasalahan yang menarik kesimpulan, ketika mereka secara aktif memilih, menyusun, mengatur, menyentuh, merencanakan, menyelidiki, mempertanyakan, dan membuat keputusan, mereka mengaitkan isi materi dengan konteks dalam kehidupan nyata, dan dengan cara ini mereka menemukan makna.

Dalam hal untuk meningkatkan aktivitas dan memudahkan siswa menghafal dan mengingat dalam jangka waktu lama terhadap konten materi tentang aktivitas ekonomi yang berkaitan dengan sumber daya alam dan 
potensi lain di daerahnya, selain menggunakan pemanfaatan lingkungan sekitar dibantu juga dengan teknik mind mapping.

Mind Mapping adalah alternatif pembelajaran aktif, dimana siswa dikutsertakan berfikir aktif dalam pembelajaran. Mind Mapping merupakan salah satu cara mencatat materi pelajaran yang memudahkan siswa belajar karena siswa hanya mencatat inti masalah, kemudian membuat peta pikirannya masing-masing atas kreativitasnya sendiri. Menurut Buzan (2012:4) Mind Map adalah cara termudah untuk menempatkan informasi ke dalam otak dan mengambil informasi ke luar dari otak, yang merupakan cara mencatat yang kreatif, efektif, dan secara harfiah akan 'memetakan' pikiran-pikiran kita. Peta pikiran merupakan alat yang membantu otak berpikir secara teratur.

Mind Map adalah sistem belajar dan berpikir yang menggunakan kedua belah otak sesuai dengan cara kerja alaminya. Dari definisi tersebut, dapat dikatakan bahwa mind map merupakan metode belajar yang memaksimalkan kerja otak kanan dan otak kiri sehingga otak mengalami keseimbangan dalam bekerja (Windura, 2013:12). Gambar dan warna-warna dalam mind map adalah bagian kerja otak kanan, sedangkan informasi yang ada didalamnya adalah bagian kerja otak kiri. Apabila otak kanan yang bekerja, maka dapat menyimpan memori dalam jangka waktu yang panjang dalam otak anak. Jika digunakan bersamaan antara otak kanan dan kiri, akan dapat mengurangi resiko kejenuhan belajar akibat beban yang tidak seimbang pada otak manusia.

Sihombing (2015) dalam penelitiannya tentang penerapan pembelajaran kontekstual pada materi potensi dan persebaran sumber daya laut untuk meningkatkan motivasi dan prestasi belajar IPS siswa SMP negeri 2 Medang Deras. Sesuai data hasil penelitiannya menunjukkan bahwa dengan penerapan pembelajaran kontekstual motivasi dan prestasi belajar siswa meningkat pada tiap siklus.

Selanjutnya pada penelitian Dewi (2015) tentang Pengembangan perangkat pembelajaran contextual teaching and learning dengan media mind mapping untuk meningkatkan hasil belajar siswa pada subtema lingkungan tempat tinggalku kelas IV SD. Dalam hasil penelitiannya dijelaskan bahwa aktivitas siswa selama kegiatan belajar mengajar meningkat, respon siswa dalam pembelajaran positif, dan hasil belajar siswa setelah mengikuti pembelajaran dapat mencapai ketuntasan individu maupun klasikal. Hal ini menunjukkan bahwa pembelajaran menggunakan pendekatan CTL dengan media mind mapping terlaksana dengan efektif. Berdasarkan uraian di atas dan hasil penelitian terdahulu, maka peneliti berasumsi bahwa pemanfaatan lingkungan sekitar dengan teknik mind mapping akan meningkatkan aktivitas dan hasil belajar siswa.

Berdasarkan latar belakang di atas, maka peneliti merumuskan masalah sebagai berikut: (1) Bagaimanakah peningkatan aktivitas siswa dalam pembelajaran pemanfaatan lingkungan sekitar dengan teknik mind mapping pada mata pelajaran IPS kelas IV SDI Al-Irsyad Kota Tarakan? (2) bagaimanakah peningkatan hasil belajar siswa dalam pembelajaran pemanfaatan lingkungan sekitar dengan teknik mind mapping pada mata pelajaran IPS kelas IV SDI Al-Irsyad Kota Tarakan? Sesuai dengan rumusan masalah dalam penelitian ini maka penelitian ini bertujuan untuk (1) mendeskripsikan peningkatan aktivitas siswa dalam pembelajaran pemanfaatan lingkungan sekitar dengan teknik mind mapping untuk meningkatkan aktivitas dan hasil belajar pada mata pelajaran IPS kelas IV SDI AlIrsyad Kota Tarakan. (2) mendeskripsikan peningkatan hasil belajar siswa dalam pembelajaran pemanfaatan lingkungan sekitar dengan teknik mind mapping pada mata pelajaran IPS kelas IV SDI Al-Irsyad Kota Tarakan.

\section{METODE}

Penelitian ini merupakan jenis penelitian tindakan kelas. Fraenkel dan Wallen (2003: 572) penelitian tindakan adalah penelitian yang dilakukan oleh satu orang atau lebih secara individu atau kelompok yang bertujuan untuk menyelesaikan masalah atau memperoleh informasi dalam rangka menginformasikan praktek lokal. Desain penelitian dalam pelaksanaan PTK ini menggunakan model Kemmis dan Mc Taggart (dalam Tanujaya dan Mumu, 2016:22) dengan siklus yang dilakukan secara berulang dan berkelanjutan tergantung pada ketercapaian tujuan penelitian. Siklus tahapannya terdiri dari: perencanaan (planning), tindakan (acting) dan pengamatan (observing), serta refleksi (reflection).
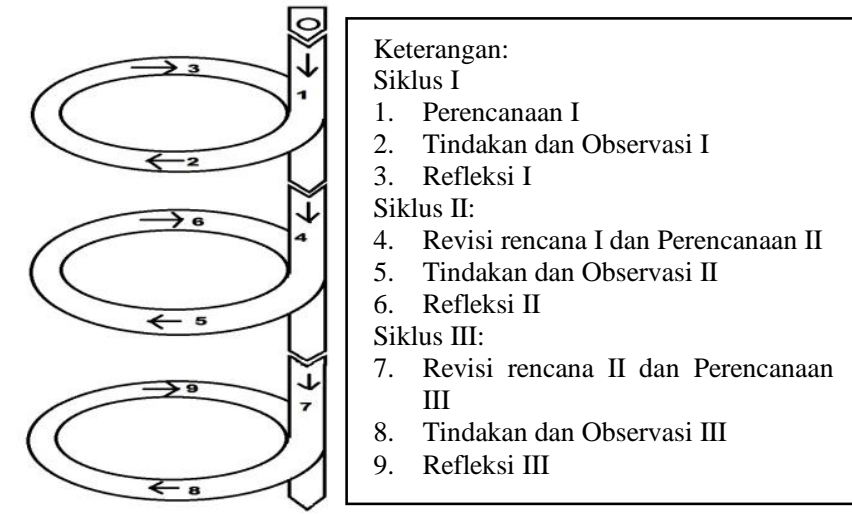

Gambar 1.

(Sumber: Kemmis dan Mc. Taggart.1988: 11) 
Berikut ini gambaran tahapan penelitian tindakan kelas yang akan dilakukan:

1. Perencanaan (planning)

Pada tahap ini, peneliti melakukan perumusan kegiatan yang diperlukan dalam penerapan pemanfaatan lingkungan sekitar dengan teknik mind mapping untuk meningkatkan aktivitas dan hasil belajar pada materi aktivitas ekonomi yang berkaitan dengan sumber daya alam dan potensi lain di daerahnya. Kegiatan yang akan dilakukan meliputi:

a. Membuat Rencana Pelaksanaan Pembelajaran (RPP) yang terdiri dari: standar kompetensi, kompetensi dasar, indikator, tujuan pembelajaran, kegiatan pembelajaran, menetapkan pendekatan dan teknik pembelajaran, sumber belajar dan evaluasi.

b. Membuat lembar observasi guru untuk mengetahui aktivitas siswa selama pembelajaran.

c. Mempersiapkan instrumen untuk merekam dan menganalisis data mengenai proses dan hasil tindakan.

2. Pelaksanaan tindakan (acting) dan pengamatan (observing)

Tahap ini merupakan implementasi atau penerapan pemanfaatan lingkungan sekitar dengan teknik mind mapping. Dalam tahap ini tindakan dan pengamatan dilakukan secara bersamaan. Sewaktu peneliti melakukan tindakan maka guru langsung melakukan pengamatan. Pengamatan dilakukan selama proses pembelajaran berlangsung menggunakan lembaran observasi.

\section{Refleksi (Reflection)}

Refleksi merupakan aktivitas yang dilakukan guru dan peneliti berdasarkan hasil pengamatan dan tindakan yang sudah dilakukan. Di tahap ini peneliti dan guru melakukan evaluasi dan revisi terhadap pembelajaran pada siklus 1 yang berupa hasil tes belajar dan lembar observasi dengan tujuan untuk mengetahui permasalahan yang dihadapi selama kegiatan berlangsung. Jika ternyata hasil yang diharapkan belum mencapai indikator keberhasilan yang ditetapkan, maka perlu dilakukan rancangan ulang sebagai bentuk revisi pada siklus 2 yang pelaksanaannya sama dengan prosedur pada siklus 1

Subjek pada penelitian ini adalah siswa kelas IV SDI Al-Irsyad Kota Tarakan Kalimantan Utara tahun pelajaran 2016/2017, dengan jumlah siswa sebanyak 30 yang terdiri dari 17 siswa dan 13 siswi Penelitian ini menggunakan teknik pengumpulan data yang meliputi: observasi, tes, dan dokumentasi. Data yang dikumpulkan berguna untuk mengetahui jawaban rumusan masalah penelitian tentang aktivitas belajar siswa dan peningkatan hasil belajar siswa. Siswono (2008:25) mendefinisikan observasi adalah upaya merekam segala peristiwa dan kegiatan yang terjadi selama tindakan perbaikan itu berlangsung dengan atau tanpa alat bantuan. Observasi yang digunakan dalam penelitian ini adalah observasi terstruktur yang disusun secara sistematis untuk mengetahui aktivitas siswa pada saat proses pembelajaran berlangsung Tes hasil belajar dalam penelitian ini adalah tes hasil belajar kognitif. Tes ini mengukur kemampuan siswa menguasai materi dan untuk mengetahui ketuntasan indikator dan ketuntasan klasikal berdasarkan KKM yang telah ditetapkan sekolah khususnya materi aktivitas ekonomi yang berkaitan dengan sumber daya alam dan potensi lain daerahnya yang diajarkan dengan memanfaatkan lingkungan sekitar dengan teknik mind mapping. Dokumentasi diwujudkan dalam bentuk foto yang memberikan gambaran konkrit aktivitas guru dan siswa selama proses pembelajaran berlangsung dari awal hingga akhir. Data hasil pengamatan setiap aspek aktivitas siswa selama kegiatan pembelajaran berlangsung dianalisis dengan menggunakan persentase. Adapun perhitungannya menggunakan rumus:

$$
\mathrm{P}=\frac{\mathrm{F}}{\mathrm{N}} \times 100 \%
$$

Keterangan:

$\mathrm{P}=$ Persentase aktivitas

$\mathrm{F}=$ Jumlah skor yang diperoleh

$\mathrm{N}=$ Jumlah skor maksimal semua komponen (Sudjana, 2016:131)

Hasil tes diolah untuk mengetahui ketuntasan hasil belajar yang dicapai siswa, dengan menggunakan rumus sebagai berikut.

$$
P=\frac{\sum X}{N} X 100
$$

Keterangan

$\mathrm{P} \quad$ : Persentase ketuntasan klasikal

$\sum \mathrm{X} \quad$ : Jumlah siswa yang mendapat nilai $\geq 70$

N : Jumlah seluruh siswa (Bungin, 2011:182)

\section{Indikator Keberhasilan}

1. Penelitian ini dikatakan berhasil dalam proses pembelajaran jika aktivitas siswa mencapai keberhasilan $\geq 80 \%$.

2. Penelitian ini dikatakan berhasil jika $80 \%$ dari jumlah siswa memiliki hasil belajar dengan nilai minimal 
yang dicapai adalah 70 . Nilai minimal tersebut sesuai dengan KKM (Kriteria Ketuntasan Minimal) yang ditentukan di SDI Al-Irsyad Kota Tarakan.

\section{HASIL DAN PEMBAHASAN}

\section{A. Aktivitas Belajar Siswa}

\section{Aktivitas Belajar Siswa Siklus I}

Berdasarkan hasil pengamatan aktivitas siswa pada siklus I dalam pembelajaran dengan pemanfaatan lingkungan sekitar yang merupakan pendekatan $C T L$ dapat diketahui bahwa nilai aktivitas siswa tidak merata dari setiap aspek yang diamati. Namun secara keseluruhan pelaksanaan komponen pendekatan CTL dapat menyebabkan siswa aktif dalam pembelajaran. Berdasarkan hasil pengamatan, dari komponen pembelajaran dengan pendekatan CTL, skor terendah pada mengajukan pertanyaan ketika mengamati, diskusi, kerja kelompok, dan menemui kesulitan (bertanya) dengan persentase $69,75 \%$. Kedua mempresentasikan hasil diskusi (pemodelan) dengan persentase $71,50 \%$. Ketiga menjawab pertanyaan/ mengerjakan LKS (inquiry) dengan persentase 73,25\%. Keempat melakukan diskusi kelompok (masyarakat belajar) dengan persentase $75,50 \%$. Kelima mengamati aktivitas ekonomi penduduk (konstruktivisme) dengan persentase $76,00 \%$. Keenam mendengarkan dan memperhatikan penjelasan guru atau siswa dengan persentase $77,50 \%$. Ketujuh membuat kesimpulan (refleksi) dengan persentase $78,25 \%$. Selanjutnya skor tertinggi mengerjakan evaluasi (penilaian autentik) dengan persentase $79,75 \%$. Nilai ratarata aktivitas siswa pada siklus I sebesar 75,19\% dengan kategori baik. Berdasarkan data tersebut diperoleh informasi ketuntasan indikator belum tercapai pada siklus I dan perlu diperbaiki pada siklus berikutnya.

\section{Aktivitas Belajar Siswa Siklus II}

Berdasarkan hasil pengamatan aktivitas siswa pada siklus II, terjadi peningkatan dari semua aspek pembelajaran dengan pemanfaatan lingkungan sekitar yang merupakan pendekatan CTL. Skor tertinggi pada aspek mengamati aktivitas ekonomi penduduk (konstruktivisme) dengan persentase $85,25 \%$. Pada urutan kedua mengerjakan evaluasi (penilaian autentik) dengan persentase $85,00 \%$. Urutan ketiga mendengarkan dan memperhatikan penjelasan guru atau siswa dengan persentase $84,25 \%$. Urutan keempat membuat simpulan (refleksi) dengan persentase $84,00 \%$. Urutan kelima melakukan diskusi kelompok (masyarakat belajar) dengan persentase $82,00 \%$. Urutan keenam menjawab/ mengerjakan LKS dengan persentase $80,25 \%$. Urutan ketujuh mempresentasikan hasil diskusi (pemodelan) $79,50 \%$. Selanjutnya perolehan terendah pada mengajukan pertanyaan ketika mengamati, diskusi, kerja kelompok dan menemui kesulitan (bertanya) dengan persentase $76,75 \%$.

Hasil pengamatan aktivitas siswa pada siklus II, menunjukkan peningkatan dari siklus I dengan rata-rata aktivitas $82,13 \%$ dengan kategori 'sangat baik'. Apabila dibandingkan dengan rata-rata aktivitas siklus I 75,19\% berarti terjadi peningkatan sebesar $6,94 \%$ dari siklus I. Aktivitas siswa pada siklus II ini juga belum tuntas, karena masih ada dua aspek yang diamati yang belum memenuhi kriteria indikator keberhasilan yang telah ditentukan peneliti yaitu $\geq 80 \%$. Untuk itu perlu adanya perbaikan di siklus berikutnya terutama pada aspek mengajukan pertanyaan ketika mengamati, diskusi, kerja kelompok, dan menemui kesulitan (bertanya) dan mempresentasikan hasil diskusi (pemodelan).

3. Aktivitas Belajara Siswa Siklus III

Berdasarkan tabel 4.9 aktivitas siswa dalam pembelajaran IPS materi pokok aktivitas ekonomi yang berkaitan dengan sumber daya alam dan potensi lain di daerahnya pada siklus III menunjukkan bahwa aktivitas yang paling tinggi adalah mengamati aktivitas ekonomi penduduk (konstruktivisme) dengan persentase 89,25\%. Kedua mendengarkan dan memperhatikan penjelasan guru atau siswa dan mengerjakan evaluasi (penilaian autentik) dengan persentase $89,00 \%$. Ketiga mengerjakan LKS (inquiri) dan membuat kesimpulan (refleksi) sebesar $87,75 \%$. Keempat melakukan diskusi kelompok (masyarakat belajar) dengan persentase $87,50 \%$. Kelima mempresentasikan hasil diskusi (pemodelan) dengan persentase $86,50 \%$. Sedangkan aktivitas yang terendah adalah mengajukan pertanyaan ketika mengamati, diskusi, kerja kelompok, dan menemui kesulitan (bertanya) dengan persentase $85,00 \%$. Berdasarkan data tersebut maka diperoleh rata-rata sebesar $87,72 \%$ dengan kategori 'baik sekali'. Hal ini berarti terjadi peningkatan sebesar 5,59\% dari siklus II. Aktivitas pada siklus III ini berarti telah tuntas, karena telah melampaui presentasi kriteria keberhasilan yang ditetapkan peneliti yaitu sebesar $80 \%$. Sehingga dapat disimpulkan bahwa aktivitas siswa telah berhasil meningkat baik dari segi proses maupun persentase yang diperoleh.

4. Peningkatan Aktivitas Siswa Siklus I-III

Proses analisis data hasil penelitian meliputi data tentang aktivitas siswa dan hasil belajar siswa mulai dari siklus I sampai dengan siklus III. Proses analisis data ini meliputi membandingkan data setiap siklus dan mengamati perkembangan hasil penelitian serta mengamati perkembangan kenaikan hasil setiap siklus. Berdasarkan hasil pengamatan observer, maka diperoleh informasi tentang aktivitas siswa dari siklus I sampai siklus III. 
Tabel 1. Rekapitulasi Hasil Observasi Aktivitas Siswa

\begin{tabular}{llcc}
\hline No & Siklus & Rata-rata & $\begin{array}{c}\text { Persentase } \\
\text { Ketercapaian }\end{array}$ \\
1 & Siklus I & 3,01 & $75,19 \%$ \\
2 & Siklus II & 3,29 & $82,13 \%$ \\
3 & SIklus III & 3,51 & $87,72 \%$ \\
\hline
\end{tabular}

Persentase keberhasilan:

$$
\begin{array}{ll}
81 \%-100 \% & =\text { Sangat Baik } \\
61 \%-80 \% & =\text { Baik } \\
41 \%-60 \% & =\text { Cukup } \\
21 \%-40 \% & =\text { Kurang (Arikunto, 2008:126) }
\end{array}
$$

Berdasarkan tabel 5.1 diatas diperoleh data persentase aktivitas siswa pada siklus I sebesar $75,19 \%$, siklus II sebesar $82,13 \%$, dan siklus III sebesar $87,72 \%$. Berdasarkan data tersebut diperoleh rata-rata $81,68 \%$ dengan kategori sangat baik. Untuk lebih jelas dapat dilihat pada grafik 5.1 berikut ini:



Grafik 1. Persentase Aktivitas Siswa Siklus I-III

\section{Keterangan Grafik:}

1. Mendengarkan dan memperhatikan penjelasan guru atau siswa

2. Mengamati aktivitas ekonomi penduduk (konstruktivisme)

3. Mengajukan pertanyaan ketika mengamati, diskusi, kerja kelompok, dan menemui kesulitan (bertanya)

4. Mengerjakan LKS (inquiry)

5. Melakukan diskusi kelompok (masyarakat belajar)

6. Mempresentasikan hasil diskusi (pemodelan)

7. Mengerjakan evaluasi (penilaian autentik)

8. Membuat kesimpulan (refleksi)

\section{B. Hasil Belajar Siswa}

\section{Hasil Belajar Siswa Siklus I}

Penilaian hasil belajar siklus I sesuai tabel 4.6 menunjukkan 19 dari 30 siswa atau 63,33\% telah mencapai kriteria ketuntasan minimal yang ditetapkan sebesar 70 . Siswa yang tuntas sebanyak 19 siswa, dengan rincian: 4 siswa memperoleh nilai 72, 5 siswa memperoleh nilai 76, 2 siswa memperoleh nilai 79, 2 siswa memperoleh nilai 83,4 siswa memperoleh nilai 86 , dan 2 siswa memperoleh nilai 90.

Sedangkan 11 siswa atau 36,66\% masih memperoleh nilai di bawah kriteria ketuntasan minimal yang ditetapkan, dengan rincian: 2 siswa memperoleh nilai 52, 4 siswa memperoleh nilai 62, 3 siswa memperoleh nilai 66, dan 2 siswa memperoleh nilai 69. Jumlah nilai hasil belajar siswa pada siklus I sebanyak 2.024, dengan nilai rata-rata kelas mencapai 73,46 dan persentase ketuntasan klasikal mencapai 63,33\%. Berdasarkan kriteria ketuntasan yang ditetapkan sebesar 70 secara perorangan dan $80 \%$ secara klasikal maka hasil evaluasi pada siklus I dinyatakan belum tuntas dan perlu ditingkatkan pada siklus II.

\section{Hasil Belajar Siswa Siklus II}

Penilaian hasil belajar pada siklus II sesuai tabel 4.3 menunjukkan 23 dari 30 siswa atau 76,66\% telah mencapai ketuntasan minimal yang ditetapkan sebesar 70. Siswa yang telah mencapai nilai ketuntasan minimal sebanyak 23 orang, dengan rincian: 4 siswa memperoleh nilai 73,5 siswa memperoleh nilai 77, 4 siswa memperoleh nilai 81,1 siswa memperoleh nilai 85,3 siswa mempeoleh nilai 88,1 siswa memperoleh nilai 92, dan 5 siswa memperoleh nilai 96.

Sedangkan 7 dari 30 siswa atau 23,33\% masih memperoleh nilai di bawah ketuntasan minimal yang ditetapkan, dengan rincian: 1 siswa memperoleh nilai 50, 1 siswa memperoleh nilai 54, 3 siswa memperoleh nilai 62,2 siswa memperoleh nilai 65. Jumlah nilai hasil belajar siswa pada siklus II sebanyak 2.342 , dengan nilai rata-rata kelas mencapai 78,06 dan persentase ketuntasan klasikal mencapai 76,66\%. Berdasarkan kriteria ketuntasan yang ditetapkan sebesar 70 secara perorangan dan $80 \%$ secara klasikal maka hasil evaluasi pada siklus II dinyatakan belum tuntas dan perlu ditingkatkan pada siklus III.

\section{Hasil Belajar Siswa Siklus III}

Penilaian hasil belajar pada siklus III sesuai tabel 4.10 menunjukkan 28 dari 30 siswa atau 93,33\% telah mencapai ketuntasan minimal yang ditetapkan sebesar 70. Siswa yang telah mencapai nilai ketuntasan minimal sebanyak 28 siswa, dengan rincian: 5 siswa memperoleh nilai 72,4 siswa memperoleh nilai 76, 3 siswa memperoleh nilai 80,4 siswa memperoleh nilai 84,3 siswa memperoleh nilai 88,1 
siswa memperoleh nilai 92, 4 siswa memperoleh nilai 96 , dan 2 siswa memperoleh nilai 100 .

Sedangkan 2 dari 30 siswa atau $6,67 \%$ masih memperoleh nilai di bawah kriteria ketuntasan minimal yang ditetapkan, dengan rincian 1 siswa memperoleh nilai 56 dan 1 siswa memperoleh nilai 64. Jumlah nilai hasil belajar siswa pada siklus III sebanyak 2.528 dengan nilai rata-rata kelas mencapai 84,26 , dan persentase ketuntasan klasikal mencapai 93,33\%. Hasil yang telah dicapai pada siklus III, menunjukkan indikator ketuntasan tercapai sehingga dapat disimpulkan peningkatan hasil belajar dengan pendekatan CTL.

\section{Peningkatan Hasil Belajar Siswa Siklus I-III}

Tabel 2. Rekapitulasi Hasil Belajar Siswa Siklus I-III

\begin{tabular}{llcc}
\hline No & Siklus & $\begin{array}{c}\text { Nilai Rata-rata } \\
\text { Hasil Belajar }\end{array}$ & $\begin{array}{c}\text { Persentase } \\
\text { Ketuntasan } \\
\text { Klasikal }\end{array}$ \\
1 & Siklus I & 73,46 & $63,33 \%$ \\
2 & Siklus II & 78,06 & $76,67 \%$ \\
3 & SIklus III & 84,26 & $93,33 \%$ \\
\hline
\end{tabular}

Berdasarkan tabel di atas diperoleh hasil ketuntasan individu, pada siklus I terdapat 11 siswa tidak tuntas, siklus II terdapat 7 siswa tidak tuntas dan siklus III terdapar 2 siswa tidak tuntas.

Secara klasikal pembelajaran dikatakan tuntas apabila $\geq 80 \%$ siswa telah mencapai KKM. Berdasarkan tabel 4.10 dapat diketahui bahwa ketuntasan klasikal untuk siklus I sebesar 63,33\%, siklus II 76,67\%, dan siklus III 93,33\%. Dari siklus I-II terjadi peningkatan sebesar 13,34\% dan dari siklus II-III peningkatan sebesar $16,66 \%$. Sehingga berdasarkan data ketuntasan individual dan persentase ketuntasan klasikal dapat disimpulkan hasil belajar siswa meningkat, pembelajaran sudah berhasil sesuai kriteria keberhasilan yang telah ditetapkan peneliti. Untuk lebih jelasnya ketuntasan klasikal hasil belajar dapat dilihat pada grafik berikut ini.

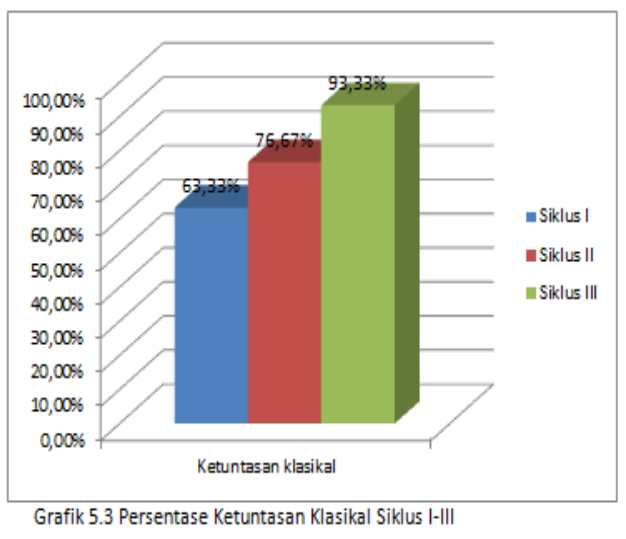

\section{Rangkuman data penelitian siklus I-III}

Berdasarkan data hasil penelitian siklus I-III, aktivitas siswa dan hasil belajar dengan pendekatan $C T L$, maka untuk lebih jelasnya dapat dirangkum pada tabel berikut.

Tabel 3. Rangkuman Data Hasil Penelitian Siklus I-III

\begin{tabular}{ccccc}
\hline No & \multicolumn{1}{c}{ Hasil } & Siklus I & Siklus & Siklus \\
& Penelitian & & II & III \\
1 & Aktivitas & 73,46 & $82,13 \%$ & $87,72 \%$ \\
& Siswa & & & \\
2 & Hasil & 78,06 & $76,67 \%$ & $93,33 \%$ \\
& Belajar & & & \\
\hline
\end{tabular}

Untuk lebih jelasnya rangkuman hasil penelitian siklus I-III dapat dilihat pada grafik 5.4 berikut ini.

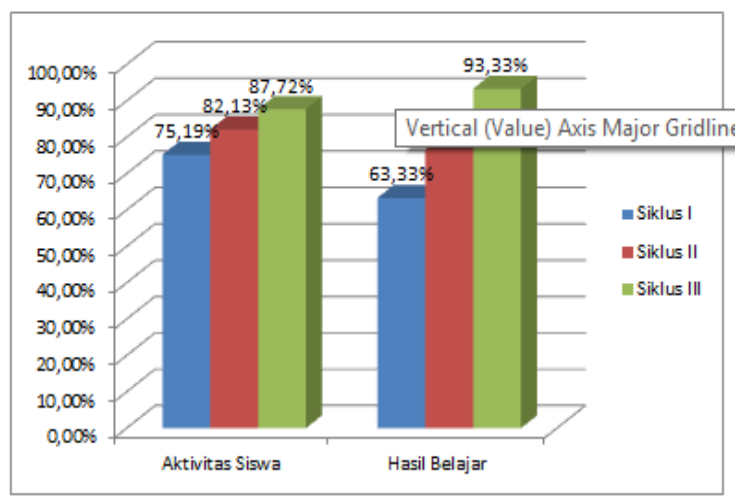

Grafik 5.4 Rangkuman Hasil Penelitian Siklus I-Siklus III

Berdasarkan hasil analisa penelitian yang diperoleh setelah kegiatan pembelajaran IPS dengan pemanfaatan lingkungan sekitar dengan teknik mind mapping, menunjukkan peningkatan aktivitas siswa pada setiap komponen pembelajaran. Sardiman (2012:95) menyatakan bahwa proses belajar tidak mungkin terjadi, tanpa ada aktivitas. Aktivitas memiliki arti yang luas, baik yang bersifat fisik maupun mental. Pengetahuan harus diperoleh melalui mendengar, melihat, mengamati, dan pengalaman sendiri. Pembelajaran dengan pemanfaatan lingkungan sekitar dengan teknik mind mapping mengajak dan memberikan kesempatan kepada siswa untuk saling tukar menukar informasi yang dimiliki sehingga siswa terlibat dalam aktivitas belajar seperti memperhatikan, mendengarkan, bertanya, memecahkan masalah, dan mengungkapkan pendapat atau gagasan. Selain itu salah satu manfaat mind mapping adalah mengembangkan imajinasi dan kreativitas siswa. Imajinasi dan kreativitas siswa yang tidak terbatas menjadikan pembuatan dan peninjauan ulang catatan lebih menyenangkan (Sugiarto, 2009:25). Dengan situasi yang menyenangkan siswa akan semakin aktif dalam pembelajaran. Hasil penelitian ini semakin diperkuat dengan penelitian dari Siti Sarofah 
(2015) dan Sama' (2016) yang menunjukkan bahwa penerapan pendekatan CTL dalam kegiatan pembelajaran efektif untuk meningkatkan aktivitas siswa.

Berdasarkan hasil evaluasi dari siklus I sampai siklus III diketahui peningkatan rata-rata hasil belajar siswa. Dengan demikian, penerapan pemanfaatan lingkungan sekitar dengan teknik mind mapping dalam penelitian ini efektif untuk meningkatkan hasil belajar siswa kelas IV SDI Al-Irsyad Kota Tarakan dalam pembelajaran IPS materi aktivitas ekonomi penduduk. Pendekatan pembelajaran merupakan unsur penting dalam menciptakan suasana belajar. Suasana belajar yang nyaman mendorong siswa aktif dalam kegiatan diskusi kelompok. Penerapan pemanfaatan lingkungan sekitar dengan teknik mind mapping dalam penelitian ini menjadikan materi lebih mudah dipahami dan diingat siswa karena siswa menemukan dan membangun pengetahuan dari pengalaman secara langsung. Konsep materi yang abstrak disajikan dalam bentuk konkret. Keunggulan dari pemanfaatan lingkungan sekitar yang merupakan pendekatan CTL adalah melalui hubungan di dalam dan di luar kelas menjadikan pengalaman lebih relevan dan berarti dalam membangun pengetahuan yang akan diterapkan dalam pembelajaran seumur hidup. Sedangkan Mind Mapping adalah teknik yang dirancang untuk membantu siswa dalam proses belajar, menyimpan informasi materi pelajaran yang diterima, dan membantu siswa menyusun inti-inti yang penting dari materi pelajaran ke dalam bentuk peta, grafik maupun penggunaan simbol sehingga siswa lebih mudah mengingat pelajaran tersebut tanpa harus mencatat keseluruhan informasi. Hasil penelitian yang dilakukan oleh Sihombing (2015) dan Dewi (2015) menunjukkan bahwa penerapan pendekatan CTL dalam pembelajaran efektif untuk meningkatkan hasil belajar siswa. Penelitian-penelitian tersebut menjadi suatu bukti bahwa pendekatan $C T L$ mampu meningkatkan hasil belajar siswa.

Pemanfaatan lingkungan sekitar dengan teknik Mind Mapping dalam penelitian ini dilakukan untuk meningkatkan aktivitas dan hasil belajar siswa kelas IV SDI Al-Irsyad Kota Tarakan dalam pembelajaran IPS. Aktivitas siswa meningkat pada masing-masing siklus, diikuti oleh hasil belajar siswa yang juga mengalami peningkatan pada setiap siklus. Dengan demikian, maka hipotesis dalam penelitian ini telah terbukti bahwa pemanfaatan lingkungan sekitar dengan teknik Mind Mapping dalam pembelajaran IPS kelas IV SDI Al-irsyad Kota Tarakan dapat meningkatkan aktivitas dan hasil belajar siswa.

\section{SIMPULAN DAN SARAN}

Berdasarkan hasil penelitian dan diskusi, maka dapat diambil beberapa simpulan sebagai berikut. (1) Pemanfaatan lingkungan sekitar dengan teknik Mind Mapping dapat meningkatkan aktivitas siswa dalam pembelajaran IPS kelas IV SDI Al-Irsyad Tarakan. Peningkatan tersebut dapat dilihat dari tercapainya indikator keberhasilan penelitian yang telah ditentukan. Ketercapaian indikator keberhasilan tersebut terjadi pada siklus III dengan persentase aktivitas siswa $\geq 80 \%$ pada delapan aspek yang diamati. (2) Pemanfaatan lingkungan sekitar dengan teknik Mind Mapping dapat meningkatkan hasil belajar siswa dalam pembelajaran IPS kelas IV SDI Al-Irsyad Tarakan. Peningkatan tersebut dapat dilihat dari tercapainya indikator keberhasilan penelitian yang telah ditentukan. Ketercapaian indikator keberhasilan tersebut terjadi pada siklus III, yaitu persentase ketuntasan hasil belajar $\geq 80 \%$ siswa yang mendapat nilai $\geq 70$.

Berdasarkan hasil penelitian yang telah dilakukan dengan pemanfaatan lingkungan sekitar dengan teknik Mind Mapping dalam pembelajaran IPS di kelas IV SDI Al-Irsyad Tarakan, peneliti dapat memberikan saran sebagai berikut: (1) Guru hendaknya menerapkan pemanfaatan lingkungan sekitar dengan teknik Mind Mapping dalam pembelajaran IPS untuk meningkatkan aktivitas belajar siswa. (2) Guru hendaknya menerapkan pemanfaatan lingkungan sekitar dengan teknik Mind Mapping dalam pembelajaran IPS untuk meningkatkan hasil belajar siswa. (3) Perlu diadakan penelitian lebih lanjut tentang penerapan pemanfaatan lingkungan sekitar dengan teknik Mind Mapping dalam pembelajaran IPS pada konteks dan materi yang lain.

\section{DAFTAR PUSTAKA}

Arikunto, suharsimi dan Cepi Safruddin Abdul Jabar. (2007). Evaluasi Program Pendidikan Pedoman Teoritis Praktis Bagi Praktisi Pendidikan. Jakarta: PT Bumi Aksara

Bungin, Burhan. (2011). Metodologi Penelitian Kuantitatif. Jakarta: Kencana Prenada Media Group

Buzan, Tony. (2012). Buku Pintar Mind Map. Jakarta. PT Gramedia Pustaka Utama

Depdiknas. 2006. Kurikulum Tingkat Satuan Pendidikan. Jakarta. Depdiknas

Dewi, Galuh Kartika. (2015) Pengembangan Perangkat Pembelajaraan Contextual Teaching and Learning dengan media Mind Mapping untuk Meningkatkan Hasil Belajar Siswa Pada Subtema Lingkungan Tempat Tinggalku Kelas IV Sekolah Dasar. Tesis Tidak dipublikasikan. 
Fraenkel, Jack R dan Norman E Wallen. (2003). How to Design and Evaluate Research In Education. New York: Jane Karpacz

Glynn, Shawn M dan Linda K Winter. (2004). Contextual Teaching and Learning of Science in Elementary Schools. Journal of Elementary Science Education, Vol. 16, No. 2 pp 51-63

Kemmis \& Mc Taggart. (1988). The Action Research Planner. Victoria: Deakin University Press.

Kosasih, E. (2014). Strategi Belajar dan Pembelajaran Implementasi Kurikulum 2013. Bandung: Yrama Widya

Peraturan Pemerintah Nomor 19 Tahun 2005 tentang Standar Nasional Pendidikan

Riyanto, Yatim. (2014). Paradigma Baru Pembelajaran. Jakarta: Kencana Prenada Media Group

Sama'. (2016). Implementasi Pendekatan Contextual Teaching and Learning Pada Pembelajaran IPS Materi Permasalahan Sosial di Masyarakat untuk Meningkatkan Aktivitas dan Hasil Belajar Siswa Kelas IV Di SDS Taman Muda Kalianget Sumenep. Tesis Tidak Dipublikasikan.

Sardiman. (2012). Interaksi dan Motivasi Belajar Mengajar. Jakarta: PT Raja Grafindo Persada

Sarofah, Siti. (2015). Penerapan Pembelajaran CTL untuk Meningkatkan Aktivitas dan Hasil Belajar Siswa Pada Mata Pelajaran IPS Kelas IV SD Canden Kabupaten Bantul. Tesis Tidak Dipublikasikan

Sihombing, Manumpak (2015). Penerapan Pembelajaran Kontekstual Pada Materi Potensi dan Persebaran Sumber Daya Laut untuk Meningkatkan Motivasi dan Prestasi Belajar IPS Siswa SMP Negeri 2 Medang Deras. Jurnal Pendidikan IPS (INTERAKSI) Vol 02 No 02 pp 123-131

Siswono, Tatag Yuli Eko. (2008). Mengajar dan Meneliti Panduan Penelitian Tindakan Kelas untuk Guru dan Calon Guru. Surabaya: Unesa University Press.

Sudjana, Nana. (2016). Penilaian Hasil Proses Belajar Mengajar. Bandung: PT Remaja Rosdakarya

Sugiarto, Iwan. (2011). Mengoptimalkan Daya kerja Otak dengan Berpikir Holistik dan Kreatif. Jakarta: Gramedia Pustaka Utama

Susanto, Ahmad. (2014). Pengembangan Pembelajaran IPS di Sekolah Dasar. Jakarta: Kencana.

Windura, Sutanto. (2013). First Mind Map Untuk siswa, Guru, \& Orang Tua Teknik Berpikir \& Belajar Sesuai Cara Kerja alami Otak. Jakarta: PT Elex Media Komputindo. 